\title{
Editorial introduction to 'Opportunity makes the thief. Really? And so what?'
}

\author{
Gloria Laycock
}

Crime Science is premised on the assumption that opportunities cause crime. For the reasons set out by Clarke (2012) it is to some a contentious statement and would almost certainly be seen as counter-intuitive by many members of the general public. It is also a powerful statement and the editorial team felt it fitting that the first substantive article in the new journal should make this point clear. In blocking opportunities for crime and terrorism we are not simply reducing the incidence, we are also removing one of the causes. For example, if it were easy to take a bomb on an aircraft then many more aircraft would explode. Making it difficult, as we do, reduces the number of bombs on aircraft and also reduces the number of motivated offenders out there prepared to act as terrorists. They do not all simply commit some other terrorist act instead; in other words the terrorism is not just displaced it is reduced. And the same effects are seen in relation to most other crimes.

The article is unusual in being an amended version of a talk by Professor Ronald V Clarke given to launch an edited book published in his honor. Although as Ronald Clarke says, much of the work described was done in collaboration with colleagues or by colleagues themselves, he was the inspiration for it.

The importance of opportunity as a cause of crime is a central issue in crime science. It opens the door to the vast array of sciences playing a part in crime control and the reduction of terrorism. Science can influence crime control in at least four ways: First, it can help us to understand the nature of crime, usually drawing on the social sciences like criminology and psychology; secondly, through the science inspired technologies, it can help to prevent crimes from happening in the first place; thirdly, it can assist the detection of offending through the forensic sciences and finally it provides us with the methods that help to test hypotheses about the opportunities that

Correspondence: g.laycock@ucl.ac.uk

UCL Department of Security and Crime Science, 35 Tavistock Square, London WC1H 9EZ, UK

\section{Springer}

(c) 2012 Laycock; licensee Springer. This is an Open Access article distributed under the terms of the Creative Commons Attribution License (http://creativecommons.org/licenses/by/2.0), which permits unrestricted use, distribution, and reproduction in any medium, provided the original work is properly cited. cause crime and the effective methods to block those opportunities, leading to the establishment of a body of knowledge and theory development. Many of these approaches depend upon the need to affect the decisions that offenders make and that is done in the context of the immediate situation within which they find themselves. Clarke expands more fully on the role of the immediate situation in his article, which we hope you enjoy reading as an informative backdrop, and for those already familiar with these arguments, as an interesting historical record.

Competing interests

I have no competing interests.

Received: 6 December 2012 Accepted: 6 December 2012

Published: 12 December 2012

\section{Reference}

Clarke, RV (2012). Opportunity Makes the Thief. Really? And so what? Crime science, in press.

doi:10.1186/2193-7680-1-2

Cite this article as: Laycock: Editorial introduction to 'Opportunity makes the thief. Really? And so what?'. Crime Science 2012 1:2.

Submit your manuscript to a SpringerOpen ${ }^{\odot}$ journal and benefit from:

- Convenient online submission

- Rigorous peer review

- Immediate publication on acceptance

- Open access: articles freely available online

- High visibility within the field

- Retaining the copyright to your article

Submit your next manuscript at $>$ springeropen.com 